\title{
Clair Engle and the brain tumor that almost derailed the Civil Rights Act
}

\author{
Colin Son, MD \\ Department of Neurosurgery, University of Texas Health Science Center, San Antonio, Texas \\ Senator Clare Engle was a United States senator from California who cast an important vote to end the filibuster of the \\ 1964 Civil Rights Act, even as a brain tumor had left him with an expressive aphasia and would claim his life just a month \\ later. This paper reviews the history of Senator Engle's illness in parallel with that of the Civil Rights Act of 1964. \\ http://thejns.org/doi/abs/10.3171/2015.4.FOCUS15106
}

KEY WORDS brain tumor; United States politics; civil rights

$\mathrm{I}$ $\mathrm{N}$ the summer of 1963 the junior senator from California began with balance issues and word-finding difficulties. ${ }^{10} \mathrm{~A}$ workup was initiated at both Bethesda Naval Hospital and the now defunct Doctor's Hospital in Washington, DC, the conclusion of which was a mass in his left cerebral hemisphere. ${ }^{8,10,20}$ The onset of Senator Clair Engle's illness corresponded to a period of great social and political upheaval and change within the United States. More than 16,000 American servicemen were already in Vietnam, while back home President John F. Kennedy would be assassinated in just a few months, Governor George Wallace was attempting to physically block the integration of the University of Alabama, and what would become the Civil Rights Act of 1964 had just been introduced in the House chamber. ${ }^{6,9,13}$ The Civil Rights Act of 1964 has proven itself as one of the most important pieces of legislation in American history. Yet Senator Engle's neurological illness nearly imperiled it. Senator Engle's decisive vote for cloture, to end the filibuster of the Civil Rights Act of 1964, despite the condition his brain tumor and its treatment had left him in, is one of the forgotten memorable moments in United States political history.

\section{Clair Engle's Early Life}

Clair Engle was born September 21, 1911, in Bakersfield, California, but would spend the majority of his childhood in the central valley of California, primarily Tehama County, where his family moved when he was only 6 months old. He settled on politics as a career early in life. While attending what today is California State University, Chico, he apparently made up his mind to try for district attorney in his home county. ${ }^{4}$ Indeed, in 1934, within a year of graduating from the University of California's Hastings School of Law in San Francisco, he was elected district attorney in Tehama County. He was just 23 years old. While at law school he met his first wife, Hazel Burney, and they eloped in 1933 just prior to his graduation. He held the office of district attorney continuously, while maintaining his own private law practice as well, until 1942, when he won election as a state senator. He was in the state capitol for less than a year, for in May of 1943 Engle's representative in the United States Congress unexpectedly died. Engle, a Democrat, won the special election for the long Republican-held California Second Congressional District. The district was a sparsely populated stretch of inner California that was the nation's second largest congressional district in terms of a geographic size at the time. ${ }^{4}$ His first marriage, to Hazel, yielded a single daughter, Yvonne. The marriage, however, ended in divorce in 1948, and later that year Clair Engle got remarried, to Lucretia Cadwell, who would be an outspoken surrogate and advocate for her husband's political career for the rest of his life.10,19 The diminutive Engle (he stood just 5 feet 6 inches tall) earned the nickname "Congressman Fireball" during his time in the lower chamber. ${ }^{4,19} \mathrm{He}$ was known for his colorful and, at times, aggressive language, once telling a witness

SUBMITTED February 28, 2015. ACCEPTED April 2, 2015. 
testifying before a congressional panel, "I'm sure going to throw a skunk into your henhouse." 19 He was a tireless campaigner, and such was required for his huge rural congressional district. A private pilot, he flew himself often to various campaign events throughout California. He rose to become Chairman of the Committee on the Interior and Insular Affairs until 1958 when one of the incumbent senators from California declined to run again in favor of seeking the governorship (Fig. 1). During the campaign for Senate his opponent commented on Engle's billboards, saying, "That picture makes him look like a giant and he's just a little squirt." Engle, showing his wit, retorted, "Where I come from, they measure a man from the neck up." $22 \mathrm{He}$ won election to the Senate, where he would serve until his untimely death. In 1960 Engle was briefly considered as a possible vice presidential candidate for John F. Kennedy. ${ }^{23}$

\section{The Civil Rights Act of 1964}

The Civil Rights Act of 1964 was the second federal legislative success of the more than decades-long civil rights movement. It had been called for by President John F. Kennedy in a nationally broadcasted address to the nation, prior to his assassination (available at http://www.jfk library.org/Asset-Viewer/LH8F_0Mzv0e6Ro1yEm74Ng. aspx). Following the assassination of President Kennedy, President Lyndon B. Johnson strongly supported the bill in an address to a joint session of Congress on November 27, 1963 (available at http://www.presidency.ucsb.edu/ ws/?pid=25988). The act barred discrimination in voter registration, in public accommodations including public transportation, in private accommodations including in restaurants and hotels and led the way to desegregation of public schools. ${ }^{5}$ From the beginning it was clear that passage of the bill was to depend on the Senate. While obscured over the years by the narrative history of civil rights legislation, the bill actually appeared to have large majority public support and easily passed the United States House of Representatives as H.R. 7152 on February 10, 1964. However, the rules of the United States Senate were, and continue to be, much more burdensome than those of the House of Representatives. The filibuster, a process unknown to the House of Representatives or most other national legislative bodies, has been called "the Senate's most characteristic procedural feature." ${ }^{3}$ The rules of the Senate allow a senator, or senators, once they have been granted the floor during a debate to continue talking as long as they wish. In practice it allows opposition senators to continue debate on a bill or other measure they disagree with indefinitely so as to postpone a vote on an issue that has majority support. The rules of the Senate held that debate, and thus a filibuster, can only be limited by a cloture vote. Such a vote required not a simple majority of senators but two-thirds. ${ }^{3}$ The filibuster was not an idle threat either; in 1944 an attempt to make the Fair Employment Practices Commission, a body designed to prevent discrimination on the basis of race for employers with government contracts, failed when two-thirds of the Senate could not be mustered to break a filibuster of southern Democrats. ${ }^{17}$ Strong opposition from a minority faction of the Senate quickly arose

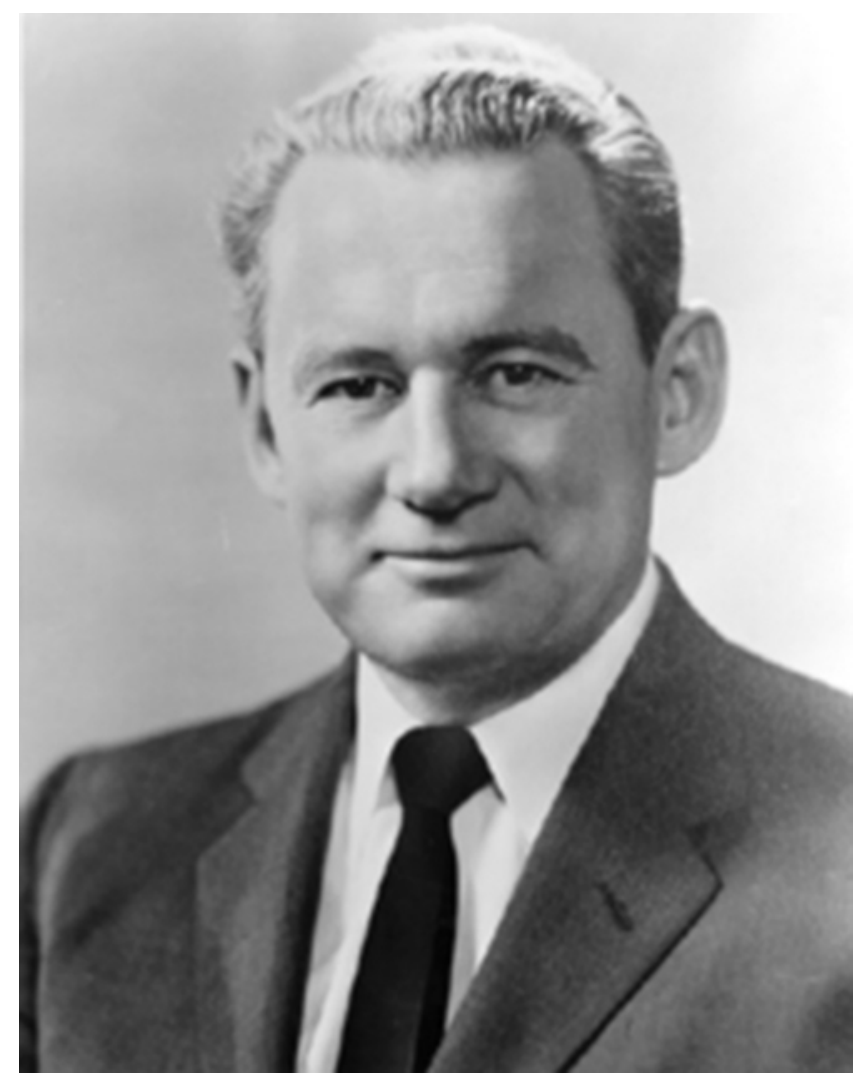

FIG. 1. Senator Clair Engle's official United States Senate portrait (in the public domain).

to the Civil Rights Act of 1964. Seventeen southern Democrats and a single Republican promised to block the legislation by filibuster. ${ }^{24}$ While this did not constitute a third of the Senate caucus, many other senators were wary to invoke cloture either out of respect for the idea of unlimited debate or because they themselves did not have full-hearted support of the bill. ${ }^{24}$ Sixty-seven votes would need to be corralled to end the filibuster and invoke cloture; it would be no small task to get them. What cloture did have was the vote of Clair Engle.

\section{Clair Engle's Brain Tumor}

In late August of 1963 Clair Engle was admitted to Doctor's Hospital in Washington, DC. His admission apparently came as a surprise to many, and the public display of his symptoms must have not been dramatic. ${ }^{22}$ Yet his symptoms, primarily consisting of balance and gait problems, apparently had been going on for weeks. ${ }^{10}$ By 1963 the diagnostic study of supposed intracranial masses had moved past simple ventriculograms and primarily consisted of cerebral angiography and nuclear studies by the intraarterial injection of various isotopes with scalp readings of emitted gamma radiation. ${ }^{11,26,27}$ Engle was found with a left cerebral mass following admission, and on August 24,1963 , he underwent a craniotomy. ${ }^{10,19}$ What was discovered was described to the senator and his wife as a "malignant" brain tumor. ${ }^{10}$ The exact pathology of Engle's brain tumor was never made public or even, per the reporting of his wife, made known to her or her husband. 
However, the description of the tumor as malignant, the lack of findings elsewhere in Engle's workup, his rapid decline, and subsequent radiotherapy make glioblastoma multiforme the likely diagnosis. The consequences of his first surgery were dramatic and immediate. He awoke from surgery with a significant right hemiparesis and an expressive aphasia..$^{10} \mathrm{He}$ would spend months as an inpatient and considerable time following discharge with speech and physical therapy. ${ }^{10}$ Following his operating in August, Engle made no public appearances until November 24, briefly as Kennedy's casket laid in state at the Capitol.$^{19} \mathrm{He}$ was absent from the official Senate photo in September. ${ }^{20}$ During part of that time Engle was undergoing continued treatment in addition to his speech and physical therapy. His adjuvant postoperative therapy consisted of ${ }^{60} \mathrm{Co}$ beam radiotherapy. ${ }^{20}$ Radiation therapy had become a mainstay of glioblastoma multiforme treatment by that time. ${ }^{11,28}$ Various sources, including implanted and intraarterial, had been used, but external beam, including cobalt sources, were much more frequent. ${ }^{12,21,25,28}$ Engle appeared to be making progress. He was ambulatory with some assistance and his speech had improved, at least when he was not under duress, by the new year. ${ }^{10}$ His symptoms, however, started worsening in March $1964 .{ }^{10}$ On April 13, 1964, Engle attempted to speak for the first time since his treatment on the Senate floor. As The New York Times described the situation,

The Senator rose to his feet, assisted by two aides, stood silently for a minute and then uttered an unintelligible sound.

Senator Pat McNamara of Michigan offered to introduce the resolution for him. The California Senator nodded assent. After sitting in his chair for a few minutes, Senator Engle was virtually carried from the chamber by his aides. ${ }^{19}$

Ten days later he was back at Doctor's Hospital where the physicians told him and his wife the pressure was reaccumulating, which was expected. ${ }^{10}$ Engle underwent a second craniotomy and tumor evacuation to relieve the pressure the day following his admission.,19

In January, Engle had announced, controversially, that he would seek reelection. ${ }^{10,20}$ His condition was felt by Democratic leaders and political competitors to be more serious than implied by Engle, his wife, and his supporters. Indeed, the physicians routinely following Engle at Bethesda Naval Hospital had told President Kennedy that Engle's situation was not good prior to the Kennedy assassination in November. ${ }^{20,22}$ Engle's announcement for reelection consisted of a film, which was highly edited, as the senator's expressive aphasia, although improved some since the immediate postoperative period, limited him from speaking in complete sentences. ${ }^{20}$ Likely because of his condition, despite his incumbency, four Democratic candidates dared to challenge Engle in the June 1964 primary, including President Kennedy's former press secretary, Pierre Salinger. ${ }^{16}$

Engle himself, however, would end up not challenging in the primary. Trailing in the polls, and the severity of his condition now clear even to his family, Engle, from his hospital bed 4 days after his second craniotomy, withdrew from the race. Indeed, he appears to have been considering such even prior to his second surgery. ${ }^{2}$
Although now a lame-duck senator and with his health rapidly declining further, Engle's role in history was not done, not as the Senate considered the Civil Rights Act of 1964 that spring and summer.

\section{The Cloture Vote}

The Civil Rights Act of 1964, having passed the House of Representatives, came to the floor of the United States Senate for debate on March 30, $1964 .{ }^{5}$ Eighteen senators led a coordinated filibuster of the bill. No other bill or business not pertaining to the Civil Rights Act would be considered while the debate continued. The senators coordinating the filibuster were determined to make sure such carried on by taking turns giving lengthy speeches on the Senate floor. Senator Richard Russell of Georgia, widely viewed as the leading figure of the filibuster, said this of the legislation, "We will resist to the bitter end any measure or any movement which would have a tendency to bring about social equality and intermingling and amalgamation of the races in our (Southern) states."18 During the time of this debate, Engle would manage only two appearances on the Senate floor, including April 13, as previously described. ${ }^{19}$ Behind the scenes, Senate leaders were attempting to gather the two-thirds majority necessary to invoked cloture. On June 1, 1964, the Senate Majority Leader, Mike Mansfield, announced he would file a cloture motion. Such a motion would limit further debate to 30 more hours. ${ }^{15}$ However, while close, it was not clear that the 67 votes needed to invoke cloture were completely there at the time Senator Mansfield made his announcement. Senator Mansfield had determined, "You have to hit bedrock sometime [...and] have to have a showdown." ${ }^{24}$ By June, Engle was back in the hospital but kept abreast of the progress of the Civil Rights Act. ${ }^{10}$ Prior to the cloture motion, Senator Robert Byrd gave the longest individual speech of the filibuster, carrying on for more than 14 hours against the Civil Rights Act. ${ }^{24}$ When the day of the cloture vote came, June 10, 1964, Engle was transported by ambulance to the Capitol, determined to make his vote count. ${ }^{4,19}$ Bound now to a wheelchair, Engle was rolled into the Senate chamber. The historian Dennis W. Johnson describes the cloture vote as such,

Promptly at 11:00 a.m., the clerk began calling roll. 'Mr. Aiken.' 'Aye,' announced George D. Aiken (RepublicanVermont). 'Mr. Allot.' 'Aye,' replied Gordon Allot (Republican-Colorado). When the clerk got down to 'E,' the Senate reached a moment of high drama, rarely seen in its history.

Clair Engle was the hundredth Senator present, and he was determined to have his vote count. Gallery spectators watched in respectful silence as several times Engle weakly lifted his crippled arm, pointed to his eye, and tried to mouth the word 'Aye.' There were tears in the eyes of many of his distinguished colleagues. Senate procedure did not require that a vote be uttered out loud, and Engle's vote was recorded in the 'Aye' column. ${ }^{15}$

The cloture measure would pass by 3 votes. It was a narrow margin and the first time in the history of the United States Senate that cloture would be invoked on a civil rights bill and only the second time since 1927 on any measure. ${ }^{14}$ Engle would return again by ambulance 
9 days later on June 19, 1964, when the Senate voted officially to pass the Civil Rights Act of $1964 .{ }^{19}$ It was the last time Engle would be on the Senate floor. He died just over a month later, July 30, 1964, at the home he and his wife maintained in Washington, DC.,19 $\mathrm{He}$ was only 52 years old.

\section{Clair Engle's Legacy}

Senator Clair Engle is a poorly remembered character in American political history; he deserves more credit than that. Despite progress in the interim, to this day primary malignant brain tumors, especially glioblastoma multiforme, carry a limited life expectancy and significant morbidity for most facing them. ${ }^{7}$ Engle's fight and insistence to be a part of one of the most important pieces of legislation in American history is inspirational and a reminder of what is possible even when facing terminal neurological illness.

\section{References}

1. Associated Press: California's Sen. Engle dead at 52. Victoria Advocate. July 31,1964; p 1

2. Associated Press: Engle may withdraw. Lawrence Daily Journal-World. April 22,1964; p 16

3. Beth RS, Heitshusen V: Filibusters and Cloture in the Senate. Washington, DC: Congressional Research Service, 2014

4. Bezis JA: Death of Sen. Clair Engle: Half century later. Red Bluff Daily News. August 7, 2014. (http://www.redbluffdaily news.com/general-news/20140807/death-of-sen-clair-englehalf-century-later) [Accessed April 24, 2015]

5. Civil Rights Act of 1964, Pub.L. 88-352, 78 Stat. 241 (1964)

6. Clark EC: The Schoolhouse Door: Segregation's Last Stand at the University of Alabama. New York: Oxford University Press, 1995

7. Darefsky AS, King JT Jr, Dubrow R: Adult glioblastoma multiforme survival in the temozolomide era: a populationbased analysis of Surveillance, Epidemiology, and End Results registries. Cancer 118:2163-2172, 2012

8. DeFerrari J: Doctors Hospital, a 'Hotel for the Sick'. Streets of Washington. (http://www.streetsofwashington. com/2010/10/doctors-hospital-hotel-for-sick.html) [Accessed April 27, 2015]

9. Department of Defense: Vietnam War casualty summary. Defense Casualty Analysis System. (https://www.dmdc.osd. mil/dcas/pages/casualties_vietnam.xhtml) [Accessed April 27, 2015]

10. Engle L: Clair Engle as campaigner \& statesman, in Fry AR, Morris G, Rowland J, et al (eds): Political Advocacy \& Loyalty. Berkley: University of California, 1982

11. Frankel SA, German WJ: Glioblastoma multiforme. Review of 219 cases with regard to natural history, pathology, diagnostic methods, and treatment. J Neurosurg 15:489-503, 1958
12. Freid JR, Goldberg H, Tenzel W, Okrainetz CL, Aral MI: Cobalt 60 beam therapy: three years experience at Montefiore Hospital (New York). Radiology 67:200-209, 1956

13. Gittinger T, Fischer A: LBJ champions the Civil Rights Act of 1964. Prologue Magazine. (http://www.archives.gov/ publications/prologue/2004/summer/civil-rights-act-1.html) [Accessed April 27, 2015]

14. Graham HD: The Civil Rights Era: Origins and Development of National Policy. New York: Oxford University Press, 1990

15. Johnson DW: The Laws That Shaped America: Fifteen Acts of Congress and Their Lasting Impact. New York: Routledge, 2009

16. Johnson RD: All The Way with LBJ: The 1964 Presidential Election. New York: Cambridge University Press, 2009

17. Library of Congress: Dennis Chavez. Hispanic Americans in Congress, 1822-1995. (http://www.loc.gov/rr/hispanic/ congress/chavez.html) [Accessed April 27, 2015]

18. Napolitano A: Dred Scott's Revenge: A Legal History of Race and Freedom in America. Nashville: Thomas Nelson, 2009

19. New York Times: Senator Clair Engle of California dies. July 31, 1964. (http://www.nytimes.com/1964/07/31/senator-clairengle-of-california-dies.html)[Accessed April 27, 2015]

20. Pearson D: Engle's disability a delicate problem; wife pushing him. The Bulletin. January 14, 1964; p 4 (col. 3)

21. Peirce CB, Bouchard J: Role of radiation therapy in the control of malignant neoplasms of the brain and brain stem. Radiology 55:337-343, 1950

22. Salinger P: With Kennedy. Berkley: University of California Press, 1966

23. Senate Historical Office: Clair Engle: a featured biography. United States Senate Historical Office. (http://www.senate. gov/artandhistory/history/common/generic/Featured_Bio_ EngleClair.htm)[Accessed April 27, 2015]

24. Senate Historical Office: The Senate and Civil Rights: cloture and final passage of the Civil Rights Act of 1964. United States Senate Historical Office. (http://www.senate. gov/artandhistory/history/civil_rights/cloture_finalpassage. htm) [Accessed April 27, 2015]

25. Smith IH: Cobalt 60 beam therapy: some impressions after five years. Can Med Assoc J 77:289-297, 1957

26. Sweet WH: The uses of nuclear disintegration in the diagnosis and treatment of brain tumor. N Engl J Med 245:875878,1951

27. Sweet WH, Brownell GL: Localization of intracranial lesions by scanning with positron-emitting arsenic. J Am Med Assoc 157:1183-1188, 1955

28. Wilson CB: Glioblastoma multiforme: Present status. Arch Neurol 11:562-568, 1964

\section{Correspondence}

Colin Son, Department of Neurosurgery, University of Texas Health Science Center, 7703 Floyd Curl Dr., MC 7843, San Antonio, TX 78212.email: sonc2@uthscsa.edu. 